\title{
Patrilocality and Child Sex Ratios in India
}

\author{
Srinivas Goli \\ Australia India Institute New Generation Networks Scholar, \\ The University of Western Australia, Perth, Australia \\ Assistant Professor, Centre for the Study of Regional Development, \\ Jawaharlal Nehru University, New Delhi, India.

\section{Somya Arora} \\ Research Associate, Centre for the Study of Regional Development, \\ Jawaharlal Nehru University, New Delhi, India.

\section{Neha Jain} \\ Assistant Professor of Economics, \\ Indian Institute of Foreign Trade (IIFT), \\ New Delhi, India.

\section{Sekher T.V.} \\ Department of Family \& Generations, \\ International Institute for Population Sciences (IIPS) \\ Mumbai, India. \\ Corresponding author: srinivas.goli@uwa.edu.au; \\ sirispeaks2u@gmail.com
}

28 January 2022 


\title{
Patrilocality and Child Sex Ratios in India
}

\begin{abstract}
In multi-level and multi-layered foundations of gendered approaches for understanding the kinship system, son preferences, and male-skewed child sex ratios in India; patriarchy, and patrilineality have received greater attention than patrilocality. To fill this gap, in this study, we construct a measure of patrilocality and examine its association with skewed child sex ratios. We hypothesize that households practice sex selection and daughter discrimination because of patrilocal norms that dictate the later life co-residence between parents and sons. Our findings reveal that the child sex ratio, the sex ratio at birth, and the sex ratio at last birth are positively correlated with the patrilocality rates across states and districts of India. The relationship holds across the multiple robustness checks. Findings, although not surprising, emerge from the robust empirical analyses at a time when child sex ratios continue to worsen in India, notwithstanding the country's socioeconomic progress. We conclude that in the absence of strong social security measures and lack of preference for old-age homes amidst the accepted practice of patrilocality coupled with increasing lower fertility norms, the dependency on sons will continue and further lead to the continuation of sex selection in India.
\end{abstract}

Keywords: Child Sex Ratios, Gender, Patriarchy, Patrilocality, India

JEL Classification Numbers: B54, J1, J16, C23

\section{Introduction}

Sex Ratio-the proportion of females relative to males in a population is a fundamental measure used across multiple disciplines ranging from demography, anthropology, sociology, and others for assessing population composition, gender equity, and women's status. Primarily, the sex ratio is measured at birth, 0-6 populations, and at all populations. India is the second-largest country that has notably unbalanced sex ratios in favor of males. India's sex ratio at birth (SRB: females per 1000 males at birth) as recorded by Sample Registration System (SRS) has seen a declining trend, from 906 in 2011 to 899 in 2018 (Office of RGI, 2011, 2018). Similarly, child sex ratios (CSR-number of females per 1000 males between the age group of 0-6 years) have decreased from 964 in 1971 to 953 in 1991, 927 in 2001 to 918 in 2011. Moreover, Sex Ratio at Last Birth (SRLB) calculated from the household surveys reveals that the second-order births, when the firstborn was a girl, have worsened from 906 in 1990 to 836 in 2005 (Retherford \& Roy, 2003; Bhat \& Zavier, 2007); while for third-order births, if the two previous births were girls, SRLB was even lesser (Kumari \& Goli, 2021). Although the latest factsheets of the National Family Health Survey show a slight improvement in SRB over its previous rounds, it is still far from the natural balance, and the regional imbalance continues to persist (IIPS and ICF, 2021).

Surprisingly, the skewed ratios are coinciding with the reduction in overall child mortality rates, fertility rates, better healthcare, education, and income levels, as well as continuous progress towards women's rights, and equal opportunities (Agnihotri, 2000; Jayaraj and Subramanian, 2004; John, 2018; James, Rajan, \& Goli, 2020; Kumari \& Goli, 2021). Falling CSRs and SRBs, notwithstanding the overall gender development (Arokiasamy \& Goli, 2012; Kumari \& Goli, 2021), compels us to explore the factors working behind it. If not addressed, the sex-ratio imbalance will have alarming consequences on the marriage and family-building process, violence against women, and overall human development (Sekher \& Hatti, 2010; Dyson, 2012; South, Trent, \& Bose, 2014; Kaur 2020; Filser, Barclay, Beckley, Uggla, \& Schnettler, 2021). 
The current literature on sex ratios has studied a range of issues, such as the trends of missing girls (Kishor, 1993; Das Gupta, et al., 2003; Guilmoto, 2007; Guilmoto, 2012; Arokiasamy \& Goli, 2012; Jayachandran, 2015), the transition of sex-ratio imbalances (Guilmoto, 2009; 2012; Tafuro \& Guilmoto, 2020; Kulkarni, 2020), micro geographical variation (Srinivasan \& Bedi, 2008) and sex-selective abortions (Sudha \& Rajan, 1999; Kulkarni, 2007; Jha, et al., 2011) but not many studies have explored the empirical association of patriarchy and sex ratio imbalance. In multilevel and multi-layered foundations of gendered approaches for understanding the kinship system, son preferences, and male-skewed child sex ratios in India; patriarchy, and patrilineality have received greater attention than patrilocality (Kishor, 1993; Malhotra, Vanneman, \& Kishor, 1995; Das Gupta, et al., 2003; Pande \& Astone, 2007; Kaur \& Vasudev, 2019). For example, studies have associated kinship structure with variables such as female autonomy, education, and property rights (Dyson \& Moore, 1983; Agarwal, 1986; Hudson, Bowen, \& Nielsen, 2011; Allendorf, 2013; Boer \& Hudson, 2017) to understand how patriarchy manifests discrimination against the girl child.

A few previous studies that empirically examined the link between patrilocality and skewed child sex ratios have fostered a strong positive association in the global context. For instance, using the ethnographic Atlas of Murdock (1965) and cross-country analyses, Ebenstein (2014) found that ethnic groups in areas with favorable land for intensive agriculture have stronger patrilocal norms, greater co-residence rates, and male-skewed sex ratios at birth. In an attempt to map the multiplicity of gender preferences and skewed sex ratios in Indonesia using 2010 census microdata, Guilmoto (2012) documented the existence of connection in patrilocal patterns and son preference in reproductive behavior.

However, there is no systematic documentation of empirical evidence regarding the correlation between the direct measure of patrilocality and child sex ratios in the Indian context. Although Kishor (1993) discusses the correlation of patrilocal exogamy and child mortality, focusing on the female labor force participation as the predictor variable while theoretically touching upon the devaluation of the female child in a patriarchal kinship system, the study does not use a direct measure of patrilocality to relate it to various indicators of child sex ratios. To fill this gap, in this study, we construct a measure of patrilocality and examine its association with skewed child sex ratios. We hypothesize that households practice sex selection and daughter discrimination because of patrilocal norms that dictate later life co-residence between parents and sons and thus demand an empirical investigation. In the absence of strong social security measures and lack of preference for old-age homes amidst the accepted practice of patrilocality coupled with increasing lower fertility norms (Berkman, Sekher, Capistrant, \& Zheng, 2012; Barik, Agrawal, \& Desai, 2015; Chakravorty, Goli, \& James, 2021), the dependency on sons will continue and further lead to the continuation of sex selection in India.

This paper makes two critical contributions: (1) for the first time it provides a direct measure of patrilocality using Census of India information both at the state and district levels. (2) It systematically establishes the correlation between state and district level measures of patrilocality and child sex ratios. Our empirical findings support a strong positive correlation in the level of patrilocality and male-skewed child sex ratios in India. These results are also confirmed with multiple robustness checks. The remainder of the paper is arranged as follows- Section 2 provides the background and literature review on the trends in child sex ratios and the associated factors. Section 3 theoretically presents mechanisms showing the effect of patrilocality on the child sex ratio. Section 4 discusses the dataset, model, and empirical strategy applied to assess the effect of patrilocality on sex ratios. Section 5 discusses the main findings with the robustness checks while Section 6 concludes the arguments. 


\section{Background and Literature Review}

Patriarchy, defined by Eisenstein (1979), is a 'sexual system of power in which the male possesses superior power and economic privilege'. A more elaborative definition given by feminist Marilyn French-patriarchy is 'the manifestation and institutionalization of male dominance over women and children in the family and the extension of male dominance over women in society in general.' It does not make way for gender equality, rather, raises controls over women and curtail their autonomy (Agarwal, 1986). Marriage in India is one such patriarchy inclined institution that drives majority of female migrate after marriage to In-laws place, wherein women are expected to abide by the patrilocal standard-trail behind the male bread-winner and enable them restore their masculinity and patriarchal order at the cost of their autonomy, especially in terms of career development (Palriwala \& Uberoi, 2008). The patriarchal tendencies are noticed even in international marriage migrations that women at times choose to escape the very same domestic patriarchy, leaving them to be 'unpaid reproductive labor migrants' (Kim, 2010). Such patriarchal norms and institutions continue to reinforce and exacerbate women's vulnerabilities regarding the right to birth, education, and command over assets, and security (Haddad \& Kanbur, 1990; Allendorf, 2013; UNDP, 2014).

In a global setup, a few recent studies that have attempted to analyze the prevalence of sonpreference have taken into account the part played by patrilocality and patrilineality. Guilmoto (2012) measures patrilocality in Vietnam using the data on the married children co-residing with their parents and highlights that son preference was the most compelling reason for the birth imbalances noticed after 2003. The regional variations in the sex ratios at birth were most prominent in the patrilineal societies of not only Vietnam but other countries of East and South Asia. Ebenstein (2014) has explored the trends in global sex ratio (parts of East Asia, South Asia, and the South Caucuses) to understand the relationship between 'missing girls' and patrilocal norms that define the cohabitation between parents and sons. He argues that sex-ratio and cohabitation have a positive correlation and finds evidence that parents resort to sex selection and gender discrimination because of patrilocal set-up across districts, and within districts across various groups. He emphasizes the role that sons play in being the support system of elderly parents, more than on any other cultural factor, triggering sex selection and discrimination.

Jayachandran (2015) also reports that cultural norms, such as patrilocality and male-biased funerary rites, explain the male-biased sex ratios in developing countries such as China and India, though she mentions that poverty is a factor why parents tend to invest more in a male child. She concludes that if parents had a way to get investment returns on their daughter's education and healthcare, patrilocality would not cause sex-ratio imbalances. Guilmoto (2015) studies the Indonesian marriage practices, child sex ratios, and mortality ratios obtained from 2010 census microdata, concluding that skewed child sex ratios and excess female mortality in some areas of the country connect to places where patrilocality and son-preference were in prominence. The sex ratios were close to natural rates in areas of bi-local marriage set-ups, while only a few matrilocal societies showed a preference for girls.

India is predominantly a patriarchal society with a patrilocal marriage system, barring a few northeastern and south Indian communities that are matrilocal. In the patrilocal social set-up, men are fixed at one place while women are the moving elements leaving their house/village and family, and becoming a part of husband's family set-up (Das Gupta, et al., 2000). Indian marriage system can be broadly categorized into North Indian and South Indian systems, exploring which ultimately describes why gender discrimination has its roots settled in the marriage set-up. In the north, marriages are exogamous. Girls are not married in the close-kin and are usually away from the village or district in most communities, especially among upper-caste Hindus. They don't get to 
inherit land or property as transferring any assets to a girl child brings no returns and is virtually a lost cause given that she moves away. Women's property rights are anyway not well-defined and even when they claim their rights, they face great resistance. In the south, marriage set-ups are not rigid. A daughter is generally married within her relative families to keep her near to the natal place as well as keep a check on her needs and security. Consequently, there is no major social alteration in a woman's life after marriage in the South; her freedom and agency are less controlled, and she is not at the mercy of the new people in a different land to render her a voice, unlike the case in the North. The Dowry system is not encouraged, and mutual respect and equality are maintained between the couple's families. Taking aid in need or during old age from a married daughter isn't a taboo in the South, which is why the transfer of property to her is not restricted (Visaria, 1967; Dyson \& Moore, 1983; Agarwal, 2002; Raju, 2011).

Patrilocality makes way for patrilineality-an inheritance system of land and property where males become tacit beneficiaries ${ }^{1}$. Patrilocal set-up where the married couple stays with husband's family harvests an inferior status as well as financial dependence for women; even in states where women can exercise their property rights, discriminatory traditional practices overpower formal property law (Hudson, Bowen, \& Nielsen, 2011; Boer \& Hudson, 2017). Patrilineality deepens son preference as the lineage succeeds through the male line (Das Gupta, 1987; Das Gupta, et al., 2003; Hudson, Bowen, \& Nielsen, 2015). Arokiasamy \& Goli (2012) also add to the discussion that the culture of patrilineality-'landholding patriarchy'-subverts the social, political, and economic position of women to a significant extent. Recently, the World Economic Forum (2018) emphasized that India is one of the 15 countries in the world where deep-rooted patriarchal norms hamper women from claiming and exercising their rights to property.

Patriarchy has compelling consequences on the survival of a girl child as well as on female autonomy. Indian parents don't see raising a daughter to be economically viable as all the resources and time spent on her education can't be realized by her own family amid the popular practice of patrilocality. A daughter is someone else's asset and more so, a lot of expense is incurred on her wedding in the form of dowry. A son not just gets a woman into the natal house who gives birth to his progeny. Moreover, the son also becomes old-age support for the aging parents in a country where social-security benefits are not substantial (Das Gupta, 1987; Sekher \& Hatti, 2010; Sekher \& Hatti, 2010). In the context of female autonomy ${ }^{2}$, patriarchy is characterized by the restricted movement of women leading to her weak connections with the natal-kin and other social associations; controlled sexuality and agency; limited involvement in healthcare and economic decisions related to herself and her children especially daughters; and inability to claim and exercise property rights. Consequently, a woman herself finds solace and masculine security in bearing a male child, ultimately skewing the sex-ratios further (Dyson \& Moore, 1983; Agarwal, 1986; Khalil \& Mookerjee, 2019).

\subsection{Effect of patrilocality on child sex ratio: theoretical mechanisms}

Patrilineality and patrilocality drive the cultural preference for sons and induce daughters' discrimination (Das Gupta, et al., 2003; Sundaram \& Vanneman, 2008; Rammohan \& Vu, 2018) elaborating on the Hindu ideology of perceiving men as the progenitors in patrilineal India, whereas women serve as receptacles for his "seeds". Thus, men's role is considered instrumental for perpetuating the family line whereas women's reproductive role is deemed secondary and

\footnotetext{
1 Das Gupta (1987) documented this observation in highly well-to-do landowners of Punjab who were not far behind landless people in terms of female mortality and selective discrimination; their women preferring half a daughter vis-à-vis little less than two sons.

${ }^{2}$ Female autonomy as described by Dyson and Moore (1983) is the control over one's own private space and ability - mental, social, and practical-to influence it through the needed information.
} 
"transferable" (Dube, 1988). At her natal home, her position or 'slot' within the household is considered temporary as she is expected to join her husband's family upon marriage (Das Gupta, et al., 2003; Sekher \& Hatti, 2010). In these theoretical constructs, a considerable amount of literature has addressed the issue of sex-ratio imbalance (Das Gupta, 1987; Sen, 1989; Bhat, 2002; Arnold, Kishor, \& Roy, 2002; Kishor \& Gupta, 2009; Sekher \& Hatti, 2010), while highlighting following three levels of explanatory factors ${ }^{3}$ :

Figure 1. Logical model showing factors associated with skewed child sex ratios

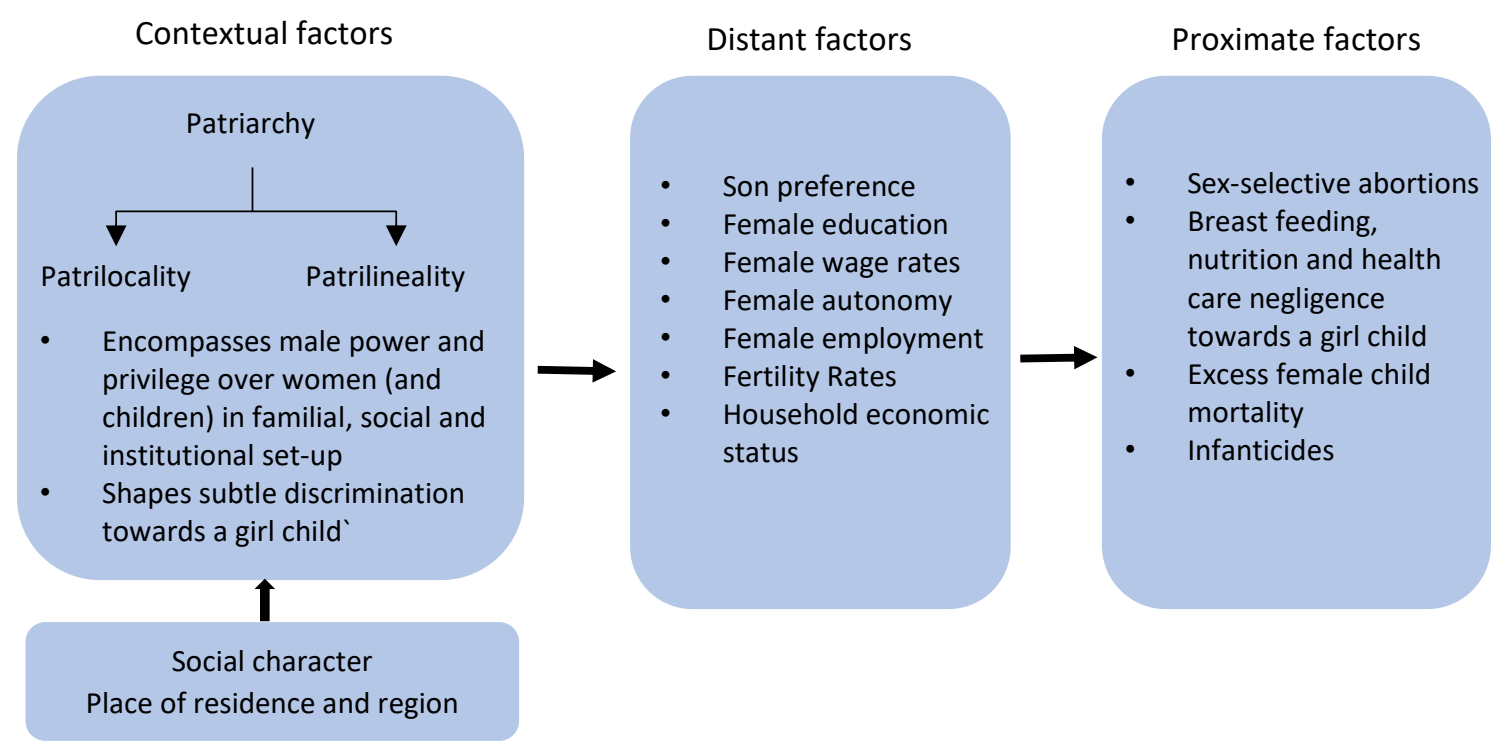

Contextual factors: Patriarchy-led patrilocality and patrilineality guide the proximate and distant factors that act as defining influencers of skewed sex ratios. Inclination towards the male child, if backtracked, leads to the entrenched patriarchal system in India, most prevalent in the northern and western regions (Dyson \& Moore, 1983; Agarwal, 2002). The likelihood of sons being the source of social and political stature is positively linked with patriarchal and male-centric kinship systems, generating female subordination and her low worth (Kishor, 1993). Across cultural traditions and religious norms, the preference is given to sons on two grounds, patrilocality-a social structure where daughters move away from their natal place to stay in husband's house after marriage; and patrilineality - a set-up where the family name and productive assets follow the male lineage (Das Gupta, et al., 2003).

The deep-rooted patriarchal ideologies curtail a woman's ability to have an identity and support herself independently without being attached to a man. For instance, according to an Indian saying: "having a daughter is like watering a flower in the neighbor's garden" (Sekher, 2010). Patriarchy further promotes male inheritance as customary practice and inequitable family laws tacitly bestow the land and property to the male lineage even when women have legal rights to inherit (Hudson, Bowen, \& Nielsen, 2011). It is reinstated by evidence (Khalil \& Mookerjee, 2019)

\footnotetext{
${ }^{3}$ These are different from the natural factors highlighted by Miller (1989) that keep the sex-ratios biologically skewed at two stages. (1) Sex-ratios tend to be high at birth, about 105, but this skewness fades away in a year due to rather high natural mortality rates of a male child compared to a female child in first year of birth. (2) Females have comparatively high mortality at their reproductive ages due to pregnancy and child birth related complexities.
} 
that women residing in patrilocal systems have relatively lower autonomy and lesser power in the household, economic, and healthcare decision-making than women in nuclear set-ups.

Distant Factors: These are the factors that indirectly and tacitly generate discrimination against a girl child, for instance, socioeconomic, demographic, and cultural indicators such as education, income levels, and traditions (Kishor, 1993; Miller, 1989; Agarwal, 2002; Guilmoto, 2007). Several studies emphasize the positive relationship between women's autonomy and empowerment and child outcomes (Duflo, 2012; Jayachandran, 2015). The extent of women's authority in the household decisions, such as household spending, is one of the parameters to judge if she has any choice in making maternity decisions. The effect of women's education, however, has mixed results. While many studies find evidence of a positive relationship between women's education and son preferences at birth and at last birth (Das Gupta, 1987; Jha, et al., 2006; Goli and Arokiasamy, 2012)_for instance, in states with relatively finer educational levels of women such as Punjab, the sex ratio at last births according to 2011 census was worse in social groups and districts with higher educated women. While other studies argue that couples who are less educated not only desire but also record the highest proportion of male children (Clark, 2000; Bhat \& Zavier, 2003). More recently, Arokiasamy and Goli (2012) and Kumari and Goli (2021) found a greater male-skewed child sex ratio among higher educated mothers compared to their lower educated counterparts. This change has occurred with greater access to sex-selective technology by higher educated women than their lower educated counterparts after the mid1980s. Two factors interact here (1) women with higher education tend to have lower fertility (hence are more driven to influence family composition) and they are also more able to aid/hinder their children's survival, while on the other hand education makes them more aware to not prefer sons over daughters. (2) less educated women follow this pattern but with some time lag, during which the strength of son preference may decline among more educated women (Das Gupta, 2019).

Similarly, SRBs are also observed to get worsen with higher wealth-sex-determination becoming more affordable for wealthy households (Guilmoto \& Depledge, 2008; Arokiasamy \& Goli, 2012; Kaur, et al., 2016; Kulkarni, 2020). As for poor people, prenatal sex selection appears to be uncommon due to a general decline in fertility and less affordability for sex-determination technology (Guilmoto, 2012). On the contrary, Jayachandran (2015) notes that poverty tends to promote skewed CSR when parents choose to spend their limited resources on sons rather than daughters. They calculate the return on their financial investment and daughters fall back in terms of returns to education and health spending.

Fertility behavior has also been discussed as a crucial reason to alter sex ratios. Low fertility levels (within small families or with governmental restrictions) limit the chances of a son being born naturally, making parents prefer a male over a female child (Guilmoto, 2007; 2012; Boer \& Hudson, 2017). Important to mention the tendency of early marriages in India affecting fertility behavior by providing a greater number of reproductive years for women to bear a male child (Dyson \& Moore, 1983). The study by Das Gupta and Mari Bhat (1997) argued that when fertility declined, an increased manifestation of gender bias was visible in India.

Sons being considered a support system in old age is yet another reason for not wanting a girl child as she is not, in economic terms, as "cost-efficient" as sons, and leaves the natal household to take care of her husband's family (Guilmoto, 2009). Male-biased cultural practices such as the execution of funerary rites by sons further devalue women's social and familial value (Das Gupta, et al., 2003).

Proximate factors: Categorized into prenatal and postnatal determinants, these are the direct factors affecting the SRB and CSR. Accessibility to prenatal diagnoses such as ultrasound and amniocentesis technology helps parents to find out the gender of their unborn child and terminate 
the pregnancy in case of an unwanted girl. Sex-selective abortions started later around the 1980s when prenatal sex-determination technology was introduced in India (Das Gupta, 1987; Agnihotri $\mathrm{S}, 2003)$. As many as 10 million sex-selective abortions are estimated to have taken place between 1981-2005 (Kulkarni, 2007), therefore, prenatal sex selection is singled out as one of the major reasons to deform gender ratios of the babies-this combined with female infanticide has generated a 'double jeopardy' for the female child (Sudha \& I Rajan, 1999; Bongaarts \& Guilmoto, 2015; Robitaille \& Chatterjee, 2018).

Research suggests that desired number of female children in most states in India is lower than the actual number, pointing to the fact that with greater accessibility to sex-determining methods, sex ratios would be even more skewed (Bongaarts, 1987; Jha, et al., 2006; Kulkarni, 2007; Kulkarni, 2012; Bongaarts \& Guilmoto, 2015). Masculinity can also be noticed at higher birth orders for couples who tend to opt for sterilization to reach a desired number of sons (Kishor \& Gupta, 2009; Kulkarni, 2020).

If she escapes prenatal sex selection, she is treated biasedly after birth leading to her low survival rates-particularly in terms of neglected medical care, nourishment, breastfeeding, etc. termed as 'female neglect' (Das Gupta, 1987; Sen, 1989; Coale, 1991), thereby risking their lives (Miller, 1989; Kuntla, Goli, \& Jain, 2014; Sharrow, et al., 2020). The impact is worse in larger families as a girl child gets divided resources having to share them with more siblings, further amplifying the female child mortality (Rosenblum, 2013).

\section{Empirical Strategy}

3.1 Data Sources: The database is compiled and studied from multiple sources at the state as well as district level for all of India. A total of 619 districts have been studied across 28 states. Telangana having formed in 2014 is included as a part of its former state, Andhra Pradesh. For empirical analysis, state-level and district-level child sex ratios are drawn from the Census of India, provided by the Registrar General of India collected every 10 years, therefore variables are compiled for the latest two Census-2001 and 2011. The main predictor variable- Patrilocality is extracted from the Census of India. The summary statistics of the variables are presented in Table 1. The means of the study variables may not match with all India averages as these are the unweighted averages of the 619 districts. We observe significant changes in means across all the variables, except two.

Table 1. Summary statistics of the study variables

\begin{tabular}{|c|c|c|c|c|c|c|}
\hline o & \multicolumn{2}{|c|}{2001} & \multicolumn{2}{|c|}{2011} & & Data source \\
\hline Variable & Mean & SD & Mean & SD & Difference & \\
\hline Patrilocality & 101.85 & 74.59 & 56.61 & 35.06 & $45.23^{\star * *}$ & Census of India (2001), (2011) \\
\hline CSR & 918.35 & 33.33 & 929.52 & 105.04 & $-11.17^{* * *}$ & Census of India (2001), (2011) \\
\hline SRB & 927.11 & 68.80 & 923.21 & 110.11 & 3.90 & Census of India (2001), (2011) \\
\hline SRLB & 928.01 & 44.25 & 814.99 & 145.63 & $113.01^{* \star \star}$ & Census of India (2001), (2011) \\
\hline $\begin{array}{l}\text { Female mean age at } \\
\text { marriage }\end{array}$ & 21.31 & 1.55 & 21.33 & 1.57 & -.01 & Census of India (2001), (2011) \\
\hline $\begin{array}{l}\text { Women with } 10 \text { years of } \\
\text { schooling or more }\end{array}$ & 41.66 & 14.39 & 33.79 & 14.17 & $7.87^{\star \star \star}$ & DLHS (2002-04), NFHS (2015-16) \\
\hline $\begin{array}{l}\text { Women's Labor Force } \\
\text { Participation Rate (LFPR) }\end{array}$ & 27.56 & 8.01 & 16.23 & 6.80 & $11.33^{\star * \star}$ & Census of India (2001), (2011) \\
\hline Total Fertility Rate (TFR) & 3.28 & 0.86 & 2.83 & 0.91 & $.44^{\star \star *}$ & Census of India, (2001), (2011) \\
\hline Women with son preference & 64.34 & 9.15 & 19.54 & 9.41 & $44.80^{* * *}$ & DLHS (2002-04), NFHS (2015-16) \\
\hline $\begin{array}{l}\text { Women with ultra-sound and } \\
\text { sonography tests as a part of } \\
\text { antenatal care visits (ANCs) }\end{array}$ & 51.23 & 25.97 & 53.43 & 25.47 & -2.20 & DLHS (2002-04), NFHS (2015-16) \\
\hline
\end{tabular}




\begin{tabular}{|l|l|l|l|l|l|l|}
\hline $\begin{array}{l}\text { Children breastfed within one } \\
\text { hour of birth }\end{array}$ & 29.22 & 19.19 & 45.05 & 20.64 & $-15.83^{\star * *}$ & DLHS (2002-04), NFHS (2015-16) \\
\hline $\begin{array}{l}\text { Households that use LPG for } \\
\text { cooking }\end{array}$ & 71.83 & 13.27 & 18.59 & 14.91 & $53.24^{\star \star *}$ & DLHS-2, NFHS-4 \\
\hline $\begin{array}{l}\text { Households with improved } \\
\text { sources of drinking water }\end{array}$ & 73.48 & 16.03 & 82.65 & 19.26 & $-9.17^{\star \star *}$ & DLHS (2002-04), NFHS (2015-16) \\
\hline $\begin{array}{l}\text { Households in low wealth } \\
\text { quintile }\end{array}$ & 47.48 & 19.71 & 19.37 & 17.65 & $28.11^{\star \star *}$ & DLHS (2002-04), NFHS (2015-16) \\
\hline \begin{tabular}{l} 
SC Population \\
\hline ST Population
\end{tabular} & 0.162 & 0.15 & 0.166 & 0.15 & $0.04^{\star * *}$ & Census of India (2001), (2011) \\
\hline $\begin{array}{l}\text { Urbanization } \\
\text { N=619 }\end{array}$ & 0.082 & 0.24 & 0.086 & 0.24 & $0.04^{\star * *}$ & Census of India (2001), (2011) \\
\hline
\end{tabular}

\subsection{Variable Description:}

Dependent Variables:

Sex Ratio at Birth: SRB is defined as the number of live female births per 1,000 live male births. The estimation procedure followed is as described in Kumar \& Sathyanarayana (2012) and Kulkarni (2020). The imbalance in the sex ratio at birth, which is the focus of this article, is engendered by the patrilocal and patrilineal setup. The census data has shown a worsening of CSR after 1981, particularly after the introduction of sex-selection methods (Guilmoto, 2007; Nandi \& Deolalikar, 2013; Kulkarni, 2020).

Child Sex Ratio: CSR is defined as the number of girls for every 1000 boys between the age group of $0-6$ years. The estimation procedure followed is as described in Kumar \& Sathyanarayana (2012) and Kulkarni (2020). Post-natal discrimination against the female child in terms of caregiving leads to excess female child mortality that skews the child sex ratios in favor of boys (Kuntla, Goli \& Jain, 2014; Robitaille \& Chatterjee, 2018). Moreover, future dowry concerns or non-affordability of her expenses lead to female infanticide. Son preference is almost tacit in patrilocal and patrilineal set-ups as females leave their natal kin and change their identity, while the family property passes along the male's line of descent as well (Tafuro \& Guilmoto, 2020; Kulkarni, 2020).

Sex Ratio at Last Birth: SRLB is defined as the ratio of females per 1000 males at the last birth of childbearing. Multiple studies have highlighted that the desire to have an additional child is greatly predicted by the sex composition of previous children. For instance, parents with male preference in childbearing opt for an additional child if the previous child is a daughter, but stop childbearing after reaching the desired sex composition of children. In the literature, this strategy is defined as 'differential stopping behavior' (DSB) that makes sex ratios unbalanced at last birth (Clark, 2000; Arokiasamy, 2007; Basu \& Jong, 2010; Kulkarni, 2020).

\section{Independent Variable:}

The variable 'patrilocality' is constructed as the ratio of female marriage migrants and male marriage migrants aged 10 to 49 years, across 619 districts. It is measured as:

$$
\text { Patrilocality }=\left(\frac{\text { Female Marriage Migration } 10-49}{\text { Male Marriage Migration } 10-49}\right)
$$

Where, marriage migration is the number of females and males between the age of 10 to 49 years migrated from the place of the last residence owing to marriage which could be-within the state of enumeration, outside the district of enumeration within the state, and elsewhere within the district of enumeration. The data is drawn from the Census D-05 series on migration which provides data points on 'Migrants by Place of Last Residence, Age, Sex, Reason for Migration 
(marriage), and Duration of Residence'. The value of Patrilocality varies from 1 to infinite, while the value less than 1 represents Matrilocality.

Figure 2 depicts the level of patrilocality in the two studied periods. The figure shows a decline in patrilocality across the district from 2001 to 2011. This recent drop in patrilocality could be due to urbanization as within city marriage migration is difficult to capture using the current census questions. In particular, in high-density metropolitan cities where the village endogamy is not so relevant, thus might be underreported. For instance, a woman married to a man in the same locality in Delhi does not report migration from the place of enumeration according to the census definition, even though there is a chance of changing the residence from natal family to in-law family. Also, urbanization contributes to the migration of couples together to cities after marriage. However, to adjust this bias, we have controlled urbanization in all our models and also conducted some interaction effects using urban dummy variables. Moreover, urbanization is a universal process, therefore to a large extent, the relative rank of the districts remains the same irrespective of their absolute patrilocality level. This is evident from Figure $1 \mathrm{~A}$.

Figure 2. Levels of Patrilocality among the districts of India in 2001 and 2011
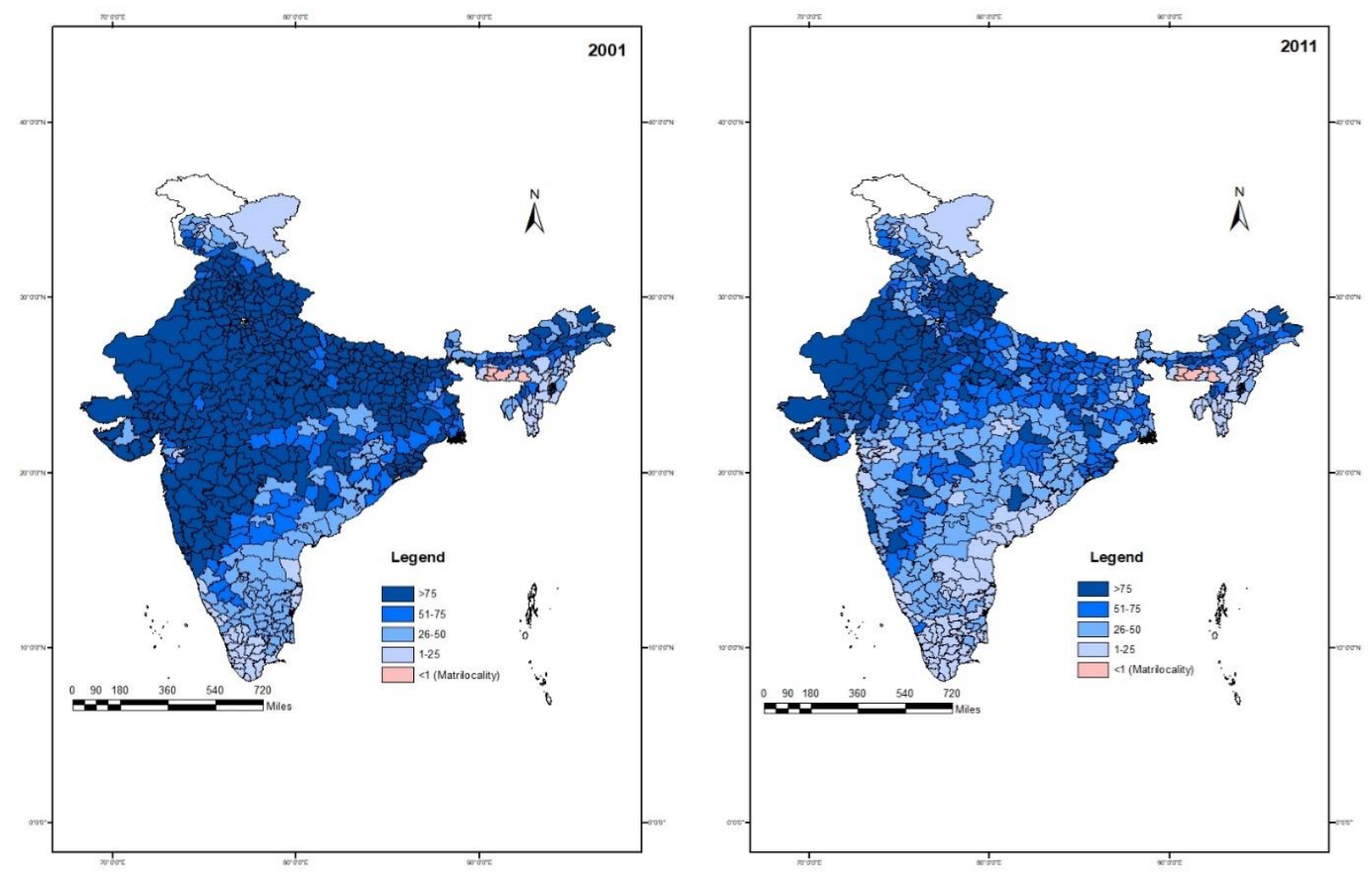

\section{Control Variables:}

Indicators of Women's autonomy comprise female mean age at marriage, women with 10 or more years of schooling (15-49 years), and women's labor force participation rate (LFPR). Dyson and Moore (1983) emphasize that in Indian kinship systems a daughter is better married off as early as possible as they place family's pride in her. Her "purity" is of greatest concern which is protected at all costs, and also, finding a partner becomes difficult with rising age, thereby 
increasing the cost of the marriage. Therefore, early marriage opens the window for a greater number of births until she bears a son. The relationship between female education and sex ratio is discussed in multiple studies. Das Gupta (1987) provides evidence of the level of female education in Punjab generating the desire of nuclear families, thus skewness in favor of a male child. Saha and Paul (2017) evince a negative association between female education and child sex ratios, especially in the highly educated districts of western states like Gujarat and Maharashtra, and a positive association in districts of the central region such as Madhya Pradesh and Chhattisgarh, characterized by tribal population. Women's contribution to the labor force improves their autonomy and tends to boost relatively equal mortality rates, as Agnihotri et al. (2002) highlight the extensive female child bias in Northern parts of India that is characterized by low female labor participation.

Demographic and health indicators include total fertility rate (TFR), mothers having at least 3 antenatal care visits during the last pregnancy, and children breastfed within one hour of birth. The desire for a male child tends to be higher in regions with high fertility (Chaudhuri, 2012), while at low levels of fertility, the sex ratio tends to become discriminated against the female child (the intensification effect) (Das Gupta \& Bhat, 1997). Multiple studies have discussed the role of health factors in the sex ratio such as institutional births favoring the female child and how ultrasound and sonography tests as a part of antenatal care were misused to determine pregnancy, leading to more abortions than live births between 1996 and 2001 (Unisa, et al., 2007; Nandi \& Deolalikar, 2013; Chao, et al., 2020).

Economic, social, and development indicators comprise the lowest wealth quintile, use of LPG for cooking, improved sources of drinking water, scheduled caste population, scheduled tribe population, son preference, and urbanization. The level of poverty captured by the first three indicators reflects if parents would push for a son's birth as sons in such a scenario become all the more valuable to earn for the family and support them during old age (Agarwal, 1986; Jayachandran, 2015). The Scheduled Caste (SC) and Scheduled Tribe (ST) population ${ }^{4}$ don't have easy access to sex determination technologies as they generally belong to income constrained social groups, earning low wages through casual and agricultural work, and also, they culturally have better women autonomy - thus display relatively balanced sex-ratios (Guilmoto \& Depledge, 2008; Saha \& Paul, 2017). India exhibits a desire for sons that exacerbates gender disparity, and given the joint family structure in India with the fixed amount of family income, daughters are more prone to differential treatment in terms of health, education, and other resources to provide for the sons, leading to female mortality (Das Gupta, 1987; Chaudhuri, 2012). Multiple shreds of evidence show that urbanization worsens sex ratios further against women as urban people have better access to sex-determining methods, thus planning their family around the sons (Agnihotri, 2003; Zavier \& Bhat, 2007; Guilmoto \& Depledge, 2008). However, the study by Saha \& Paul (2017) doesn't display a significant effect of urbanization on sex ratios.

\subsection{Model}

The study uses district-level panel data and runs fixed and random effect regression models to empirically test the hypothesis that patrilocality is detrimental for balanced childhood sex ratios. F-test is used for both fixed and random effect models while Hausman Test is applied to decide between fixed or random effects, with the null hypothesis that the preferred model is random effects vs. the fixed effects. The main equation of the Panel Data Regression Model that used is:

\footnotetext{
${ }^{4}$ SCs and STs are constitutionally categorised social groups derived from the social hierarchy of the Caste system in India. General castes, Other Backward Classes (OBCs), SCs and STs are the four social groups in the order of their hierarchy from high to low social position (Office of RGI and Census Commissioner of India, 2011).
} 
$\operatorname{CSR}_{i t}=\alpha+\beta_{0}+\beta_{1}$ Patrilocality $_{i t}+\beta_{i}$ Control variables $_{i t}+\beta_{14}$ Time dummy $+\beta_{15}$ Regional dummy $+u_{i}+v_{i t}$

Where, $C S R_{i t}$ represents the natural log of child sex ratio in district $i$ in period $\mathrm{t}$ - the dependent variable. The exact equation is used for the other two dependent variables in the study-SRB $B_{i t}$ and $S R L B_{i t}$. The main independent variable Patrilocality ${ }_{i t}$ is the natural log of patrilocality in district $i$ in period t. $\beta$ is the coefficient for independent variables. $u_{i}(\mathrm{i}=1 \ldots \mathrm{n})$ is a fixed or random effect specific to an individual district or period that is not included in the regression. $v_{i t}$ is the error term.

\section{Results}

\subsection{Main Findings}

Effect of Patrilocality on Child Sex Ratio

Table 2 applies the panel data regression model to establish the direction of the relationship between patrilocality and child sex ratios across all four models. Model 1 reports the gross effect of patrilocality on CSR before controlling for the covariates. We see that the coefficient of the explanatory variable is negative and highly significant at $1 \%$. A unit increase in patrilocality leads to 14 units $^{5}$ decrease in the child sex ratio. In other words, with every unit rise in patrilocality variable, there is a decrease of 14 girls per 1000 boys. Model 2 and 3 control for the covariates (after leaving out the variables that have pairwise correlation) to estimate the relationship between patrilocality and CSR. The coefficient of the explanatory variable is larger in magnitude and highly significant. Model 4 controls for time and region that keeps our result significant.

The coefficient of women labor force participation is positive and highly significant (around 0.037), stating that high women labor force participation is a good sign for balanced sex ratios, in line with the observations by Kishor (1993) and Agnihotri et al. (2002). The total fertility rate shows a negative and significant relationship indicating that a higher fertility rate increases the number of girls born before a boy, leaving a high chance of discrimination against them and low survival rates. Urbanization shows a negative and significant relationship which is against the common assumption that urban areas offering better facilities and exposure to women would lead to better survival of girl child.

Table 2. Random effects regression estimates: the effect of patrilocality on CSR

\begin{tabular}{lcccc}
\hline VARIABLE & Model 1 & Model 2 & Model 3 & Model 4 \\
\hline Patrilocality & $-0.0140^{* * *}$ & $-0.0138^{* * *}$ & $-0.0158^{* * *}$ & $-0.00640^{*}$ \\
& $(0.00264)$ & $(0.00309)$ & $(0.00287)$ & $(0.00336)$ \\
Female Mean Age at Marriage & & 0.0143 & 0.00119 & 0.0640 \\
& & $(0.0409)$ & $(0.0403)$ & $(0.0412)$ \\
Women with 10 years of schooling & & 0.00521 & 0.00111 & 0.00673 \\
or more & $(0.00582)$ & $(0.00563)$ & $(0.00643)$ \\
Women LFPR & $0.0219^{* * *}$ & 0.00815 & $0.0257^{* * *}$ \\
& & $(0.00642)$ & $(0.00574)$ & $(0.00661)$ \\
TFR & & $-0.00906^{* * *}$ & $-0.00644^{*}$ \\
Women with son Preference & & & $(0.00339)$ & $(0.00367)$ \\
& & $-0.00720^{*}$ & & -0.00232 \\
Children breastfed within one hour & & $(0.00427)$ & & $(0.00756)$ \\
of birth & 0.00286 & & \\
Households with Low Wealth & $(0.00419)$ & & $0.000448^{* * *}$ & $0.000832^{* * *}$
\end{tabular}

${ }^{5}$ Since, the child sex ratio is measured as number of females per 1000 males, we have multiplied the coefficients with 1000 for ease of interpretation and readers understanding. 


\begin{tabular}{|c|c|c|c|c|}
\hline \multirow{2}{*}{\multicolumn{2}{|c|}{$\begin{array}{l}\text { Quintile } \\
\text { SC Population }\end{array}$}} & & (0.000150) & $(0.000170)$ \\
\hline & & $\begin{array}{c}0.0134 \\
(0.0176)\end{array}$ & $\begin{array}{l}-0.00333 \\
(0.0173)\end{array}$ & $\begin{array}{c}0.0182 \\
(0.0173)\end{array}$ \\
\hline ST Population & & $\begin{array}{l}-0.0100 \\
(0.0107)\end{array}$ & $\begin{array}{l}-0.0122 \\
(0.0105)\end{array}$ & $\begin{array}{l}-0.0160 \\
(0.0108)\end{array}$ \\
\hline Urbanization & & $\begin{array}{l}-0.0136^{* * *} \\
(0.00365)\end{array}$ & $\begin{array}{l}-0.00969^{\star *} \\
(0.00394)\end{array}$ & $\begin{array}{l}-0.00783^{*} \\
(0.00414)\end{array}$ \\
\hline $\begin{array}{l}\text { Regional Dummy } \\
\text { Time Dummy }\end{array}$ & & & & $\begin{array}{l}\text { YES } \\
\text { YES }\end{array}$ \\
\hline Constant & $\begin{array}{l}6.882^{* * *} \\
(0.0110)\end{array}$ & $\begin{array}{c}6.808^{* * *} \\
(0.125)\end{array}$ & $\begin{array}{c}6.901^{* * *} \\
(0.131)\end{array}$ & $\begin{array}{c}6.550^{* * *} \\
(0.146)\end{array}$ \\
\hline Observations & 1,238 & 1,238 & 1,238 & 1,238 \\
\hline
\end{tabular}

Standard errors in parentheses. ${ }^{* \star *} p<0.01,{ }^{* \star} p<0.05,{ }^{*} p<0.1$

Note: All the variables used for the regression models are in log-linear form except SC population, ST population, and Wealth

\section{Effect of Patrilocality on Sex Ratio at Birth}

Table 3 shows that the coefficients of patrilocality remain statistically significant at $1 \%$ across all models. Model 1 shows a unit rise in patrilocality variable causing a fall in SRB by at least 17 units, i.e., a fall of 17 girls per 1000 boys. Other models control for the covariates (after leaving out the variables that have pairwise correlation) to estimate the relationship between patrilocality and SRB. The coefficient value is highest $(-0.027)$ for model 2 when the confounding covariates are controlled for. Model 5 controls for time and region that keeps our result significant.

The coefficient of female literacy captured by the variable 'women with 10 years of schooling or more' is positive and highly significant, meaning women's education improves SRB. Son preference shows negative and significant results confirming the common observation that higher son preference leads to a lower sex ratio at birth. The variable 'mothers with at least 3 ANCs' shows a significant negative relationship with SRB in model 3 which could be due to misuse of antenatal check for sex determination; however, when low wealth quintile is controlled in model 4 , the variable becomes insignificant that highlights less affordability for sex-selective abortion during ANCs and thereby the sex selection opportunities in poor population, hence, more balanced ratios. SC and ST populations have negative and significant correlations displaying skewed sex ratios among these populations, in contrast with the observation made by Guilmoto \& Depledge (2008).

Table 3. Random effects regression estimates: The effect of patrilocality on SRB

\begin{tabular}{|c|c|c|c|c|c|}
\hline VARIABLE & Model 1 & Model 2 & Model 3 & Model 4 & Model 5 \\
\hline Patrilocality & $\begin{array}{c}-0.0166^{* * *} \\
(0.00318)\end{array}$ & $\begin{array}{c}-0.0265^{\star * *} \\
(0.00352)\end{array}$ & $\begin{array}{l}-0.0255^{\star * *} \\
(0.00361)\end{array}$ & $\begin{array}{l}-0.0217^{* * *} \\
(0.00345)\end{array}$ & $\begin{array}{c}-0.0143^{* * *} \\
(0.00389)\end{array}$ \\
\hline $\begin{array}{l}\text { Female Mean Age at } \\
\text { Marriage }\end{array}$ & & $\begin{array}{c}0.0450 \\
(0.0486)\end{array}$ & 0.0129 & $0.0876^{*}$ & $0.105^{\star \star}$ \\
\hline $\begin{array}{l}\text { Women with } 10 \\
\text { years of schooling or } \\
\text { more }\end{array}$ & & $\begin{array}{l}0.0380^{* * *} \\
(0.00610)\end{array}$ & $\begin{array}{l}0.0325^{\star * *} \\
(0.00612)\end{array}$ & $\begin{array}{l}0.0185^{* * *} \\
(0.00620)\end{array}$ & $\begin{array}{l}0.0248^{* * *} \\
(0.00709)\end{array}$ \\
\hline Women LFPR & & $\begin{array}{c}0.0145^{* *} \\
(0.00578)\end{array}$ & $\begin{array}{l}0.0268^{* * *} \\
(0.00730)\end{array}$ & $\begin{array}{c}0.00633 \\
(0.00739)\end{array}$ & $\begin{array}{c}0.0126 \\
(0.00778)\end{array}$ \\
\hline TFR & & $\begin{array}{c}0.0441^{\star * *} \\
(0.0105)\end{array}$ & & & \\
\hline $\begin{array}{l}\text { Women with son } \\
\text { Preference }\end{array}$ & & & -0.00279 & $-0.0253^{\star * *}$ & $-0.0155^{\star}$ \\
\hline
\end{tabular}




\begin{tabular}{|c|c|c|c|c|c|}
\hline \multirow{2}{*}{\multicolumn{3}{|c|}{ Women with ultra- }} & $(0.00447)$ & $(0.00503)$ & $(0.00829)$ \\
\hline & & & $-0.0311^{\star \star *}$ & -0.00220 & -0.00130 \\
\hline sound and & & & $(0.00574)$ & $(0.00634)$ & $(0.00673)$ \\
\hline \multicolumn{6}{|l|}{$\begin{array}{l}\text { sonography tests as } \\
\text { a part of ANCs }\end{array}$} \\
\hline \multicolumn{3}{|l|}{ Households with Low } & & $0.00171^{\star \star *}$ & $0.00185^{\star * *}$ \\
\hline \multicolumn{3}{|l|}{ Wealth Quintile } & & (0.000189) & $(0.000193)$ \\
\hline \multirow{2}{*}{\multicolumn{2}{|c|}{ SC Population }} & -0.0314 & $-0.0457^{* *}$ & $-0.0477^{* *}$ & $-0.0359^{*}$ \\
\hline & & (0.0208) & $(0.0207)$ & $(0.0196)$ & $(0.0196)$ \\
\hline \multirow{2}{*}{\multicolumn{2}{|c|}{ ST Population }} & -0.00239 & -0.00394 & $-0.0285^{\star \star}$ & $-0.0240^{\star}$ \\
\hline & & $(0.0126)$ & $(0.0127)$ & $(0.0123)$ & $(0.0126)$ \\
\hline \multicolumn{2}{|l|}{ Urbanization } & $\begin{array}{l}-0.0183^{* \star *} \\
(0.00442)\end{array}$ & & & \\
\hline \multirow{2}{*}{\multicolumn{3}{|c|}{$\begin{array}{l}\text { Regional Dummy } \\
\text { Time Dummy }\end{array}$}} & & & YES \\
\hline & & & & & YES \\
\hline \multirow[t]{2}{*}{ Constant } & $6.892^{* * *}$ & $6.629^{\star \star *}$ & $6.831^{\star * *}$ & $6.613^{\star * *}$ & $6.424^{\star * *}$ \\
\hline & & & $(0.140)$ & ) & (0.104) \\
\hline Observations & 1,238 & 1,238 & 1,238 & 1,238 & 1,238 \\
\hline
\end{tabular}

Standard errors in parentheses, ${ }^{\star \star *} p<0.01,{ }^{\star \star} p<0.05,{ }^{*} p<0.1$

Note: All the variables used for the regression models are in log-linear form except SC population, ST population, and Wealth

\subsection{Robustness Checks}

4.2.1 Instrumental Variable Model: The study checks for the endogeneity of the Patrilocality variable by instrumenting it with regional dummies, because patrilocal culture displays distinct characteristics in different geographies in India (Dyson \& Moore, 1983; Agarwal, 2002; Agnihotri, 2003). The statistical expression for the model is:

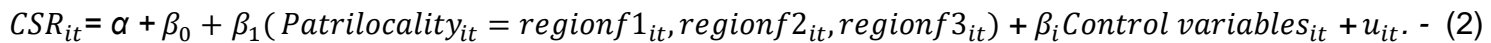

$S R B_{i t}=\alpha+\beta_{0}+\beta_{1}\left(\right.$ Patrilocality $_{i t}=$ regionf $1_{i t}$, regionf $2_{i t}$, regionf $\left.3_{i t}\right)+\beta_{i}$ Control variables $_{i t}+u_{i t} .^{-}(3)$

$S R L B_{i t}=\alpha+\beta_{0}+\beta_{1}\left(\right.$ Patrilocality $_{i t}=$ regionf $1_{i t}$, regionf $2_{i t}$, regionf $\left.3_{i t}\right)+\beta_{i}$ Control variables $_{i t}+u_{i t^{-}}(4)$

Where, $C S R_{i t}, S R B_{i t}, S R L B_{i t}$ are the dependent variables. Patrilocality $i t$ is the instrumented variable. Rest other explanatory variables have usual interpretation.

The 2SLS estimates presented in Table 5 suggest that patrilocality is an endogenous variable, as, under the endogeneity test, the null hypothesis of the exogeneity of patrilocality is rejected at a conventional level of significance. All the models (1,2, and 3 ) highlight the statistical significance of patrilocality on childhood sex ratios when instrumented by regional dummies controlling for other confounders. The instruments used are valid as per the test of over-identifying restrictions. The value of the F-statistic shows that instruments are not weakly correlated with the endogenous regressors. The results based on instrumented variable regression model also support our main findings from panel data regression models that patrilocality has a detrimental effect on the balance of childhood sex ratios. 
Table 4: Estimates of instrumental variables model (2SLS): The relationship between patrilocality and Sex ratios

\begin{tabular}{|c|c|c|c|}
\hline VARIABLE & $\begin{array}{c}\text { Model } 1 \\
\text { CSR }\end{array}$ & $\begin{array}{c}\text { Model } 2 \\
\text { SRB }\end{array}$ & $\begin{array}{c}\text { Model } 3 \\
\text { SRLB }\end{array}$ \\
\hline Patrilocality & $\begin{array}{c}-0.039^{* * *} \\
(0.011)\end{array}$ & $\begin{array}{c}-0.046^{* * *} \\
(0.011)\end{array}$ & $\begin{array}{c}-0.099^{* * *} \\
(0.015)\end{array}$ \\
\hline Women with 10 years of schooling or more & $\begin{array}{c}0.028^{* * *} \\
(0.010)\end{array}$ & $\begin{array}{c}0.065^{* * *} \\
(0.011)\end{array}$ & $\begin{array}{c}0.086^{* * *} \\
(0.015)\end{array}$ \\
\hline Women's LFPR & $\begin{array}{c}0.032^{* * *} \\
(0.010)\end{array}$ & $\begin{array}{c}0.007 \\
(0.010)\end{array}$ & $\begin{array}{l}0.029^{*} \\
(0.016)\end{array}$ \\
\hline Female mean age at marriage & $\begin{array}{l}-0.018 \\
(0.056)\end{array}$ & $\begin{array}{l}-0.003 \\
(0.064)\end{array}$ & $\begin{array}{c}0.032 \\
(0.090)\end{array}$ \\
\hline TFR & $\begin{array}{l}-0.021 \\
(0.022)\end{array}$ & $\begin{array}{c}0.076^{* * *} \\
(0.024)\end{array}$ & $\begin{array}{l}-0.058^{*} \\
(0.033)\end{array}$ \\
\hline Women with son preference & $\begin{array}{c}0.001 \\
(0.008)\end{array}$ & $\begin{array}{c}-0.019^{* *} \\
(0.009)\end{array}$ & $\begin{array}{c}0.075^{\star * *} \\
(0.012)\end{array}$ \\
\hline $\begin{array}{l}\text { Women with ultra-sound and sonography tests as } \\
\text { a part of ANCs } \\
\text { during the last pregnancy }\end{array}$ & $\begin{array}{l}-0.002 \\
(0.009)\end{array}$ & $\begin{array}{l}-0.003 \\
(0.009)\end{array}$ & $\begin{array}{l}0.026^{* *} \\
(0.013)\end{array}$ \\
\hline Children breastfed within one hour of birth & $\begin{array}{c}0.001 \\
(0.005)\end{array}$ & & \\
\hline Households that use LPG for cooking & $\begin{array}{c}-0.016^{* * *} \\
(0.005)\end{array}$ & $\begin{array}{l}-0.002 \\
(0.006)\end{array}$ & $\begin{array}{l}-0.002 \\
(0.008)\end{array}$ \\
\hline $\begin{array}{l}\text { Households with improved sources of drinking } \\
\text { water }\end{array}$ & $\begin{array}{l}-0.006 \\
(0.012)\end{array}$ & $\begin{array}{c}-0.042^{\star * *} \\
(0.014)\end{array}$ & $\begin{array}{l}0.025 \\
(0.021)\end{array}$ \\
\hline Households with low wealth quintile & $\begin{array}{l}0.011^{\star *} \\
(0.004)\end{array}$ & $\begin{array}{c}0.021^{\star \star *} \\
(0.005)\end{array}$ & $\begin{array}{c}0.029^{\star * *} \\
(0.007)\end{array}$ \\
\hline SC Population & $\begin{array}{l}-0.004 \\
(0.003)\end{array}$ & $\begin{array}{c}-0.011^{* * *} \\
(0.004)\end{array}$ & $\begin{array}{l}-0.010^{*} \\
(0.005)\end{array}$ \\
\hline ST Population & $\begin{array}{c}-0.010^{* * *} \\
(0.002)\end{array}$ & $\begin{array}{c}-0.012^{* * *} \\
(0.002)\end{array}$ & $\begin{array}{c}-0.014^{* * *} \\
(0.003)\end{array}$ \\
\hline Urbanization & $\begin{array}{l}-0.008^{*} \\
(0.005)\end{array}$ & $\begin{array}{c}-0.011^{* *} \\
(0.005)\end{array}$ & $\begin{array}{l}-0.009 \\
(0.007)\end{array}$ \\
\hline Constant & $\begin{array}{l}6.90^{\star * *} \\
(0.179)\end{array}$ & $\begin{array}{c}6.816^{\star \star \star} \\
(0.199)\end{array}$ & $\begin{array}{c}6.255^{\star \star \star} \\
(0.298)\end{array}$ \\
\hline Observations & $\begin{array}{l}1,238 \\
0,092\end{array}$ & $\begin{array}{l}1,238 \\
0201\end{array}$ & $\begin{array}{l}1,238 \\
0273\end{array}$ \\
\hline First stage F statistic & 145.72 & 145.72 & 145.72 \\
\hline \multicolumn{4}{|c|}{ Over-identifying Restrictions (Ho: zero correlation between instruments and the error term) } \\
\hline \multicolumn{4}{|c|}{$\begin{array}{lccc}\text { Score chi2 } & .668596(p=0.4135) & 5.47812(p=0.0193) & 4.1810(p=0 . \\
\text { Endogeneity of instrumented explanatory variable }(\mathrm{Ho}: \text { Variable is exogenous })\end{array}$} \\
\hline $\begin{array}{lll}\text { Robust score } & 9.60886(p=0.0019) & 4 . \\
\text { Robust regression } & 9.75816(p=0.0018) & 4 .\end{array}$ & $\begin{array}{l}6(p=0.0262) \\
1(p=0.0259)\end{array}$ & \multicolumn{2}{|c|}{$\begin{array}{l}37.7935(p=0.0000) \\
41.8521(p=0.0000)\end{array}$} \\
\hline
\end{tabular}

Robust standard errors in parentheses

${ }^{* * *} p<0.01,{ }^{* *} p<0.05,{ }^{*} p<0.1$ 
4.2.2 Path Regression Analysis ${ }^{6}$ : The relationship between patrilocality and child sex ratio can best be understood by the path regression analysis shown in Figure 3 . The arrow leading from patrilocality represents the hypothesized impact of it on the most proximate factors of child sex ratios while controlling for distant and contextual factors. It has been suggested that patrilocality statistically and significantly deepens son preference, which in turn affects the child sex ratio through two main channels-pre-natal discrimination and post-natal discrimination. The path regression diagram highlights that the higher the son preference, the higher the pre-natal discrimination (that is percentage of women having ultra-sound and sonography tests as part of antenatal care checkups) and post-natal discrimination (through breastfeeding). It is to be noted that pre-natal discrimination reduces the child sex ratios through the main channel of sex ratio at birth.

Figure 3: Path regression diagram showing the relationship between Patrilocality and Child Sex Ratio in India

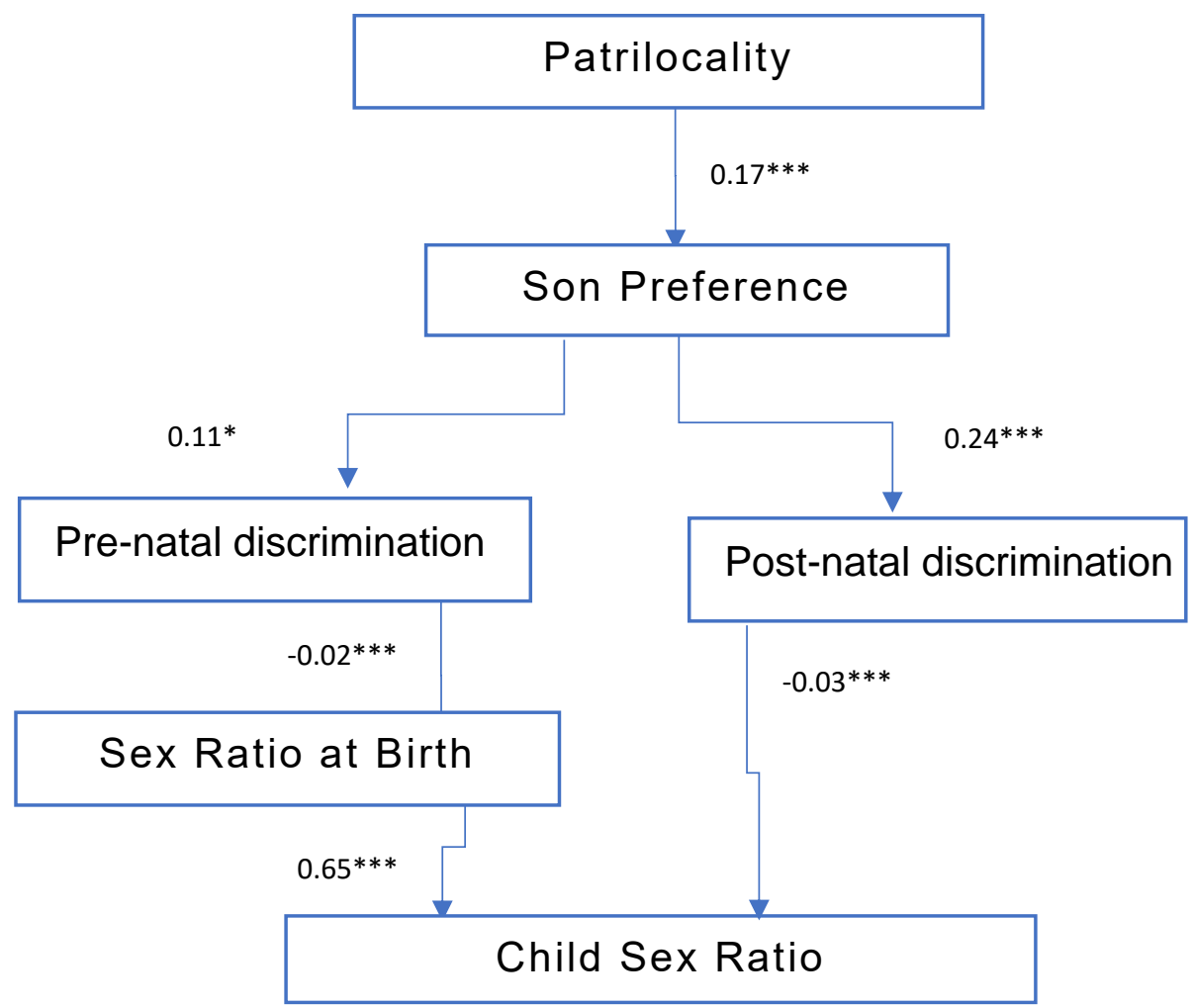

Note: Post-natal discrimination is defined as children not breastfed within one hour of birth (calculated by 100 - children breastfed within one hour of birth). Pre-natal discrimination is defined percentage of women having ultra-sound and sonography tests as part of antenatal care. All the distant and contextual factors are controlled.

\subsubsection{Effect of Patrilocality on Sex Ratios}

Table 5 shows the effect of patrilocality on sex ratios at the state level net of other relevant socioeconomic control variables. The relationship stays negatively significant for CSR, SRB, and SRLB depicting that patrilocality strongly affects these ratios even at the state analyses - thus approves our main findings using district-level analyses.

\footnotetext{
${ }^{6}$ Path regression analysis is a form of multiple regression statistical model that is used to examine causal models by establishing the relationships between a dependent variable and two or more independent variables. Mathematical proofs presented elsewhere (see, Retherford \& Choe, 2011)
} 
Table 5: Random effects regression estimates: the effect of patrilocality on sex ratios at the state-level

\begin{tabular}{|c|c|c|c|}
\hline VARIABLE & $\begin{array}{c}\text { Model } 1 \\
(\mathrm{CSR}) \\
\end{array}$ & $\begin{array}{c}\text { Model } 2 \\
(\mathrm{SRB})\end{array}$ & $\begin{array}{l}\text { Model } 3 \\
\text { (SRLB) }\end{array}$ \\
\hline Patrilocality & $\begin{array}{c}-0.0211^{* * *} \\
(0.00589)\end{array}$ & $\begin{array}{l}-0.0202^{* * *} \\
(0.00760)\end{array}$ & $\begin{array}{c}-0.0214^{\star * *} \\
(0.00764)\end{array}$ \\
\hline Control Variables & YES & YES & YES \\
\hline Constant & $\begin{array}{l}7.006^{* * *} \\
(0.0778)\end{array}$ & $\begin{array}{c}6.586^{\star \star \star} \\
(0.284)\end{array}$ & $\begin{array}{c}6.908^{* * *} \\
(0.101)\end{array}$ \\
\hline Observations & 70 & 70 & 70 \\
\hline
\end{tabular}

\subsubsection{Interaction between patrilocality and the regions}

Table 6 displays region-wise interaction of patrilocality for sex ratios at the district level, which shows that patrilocality significantly and negatively affects the sex ratio for all regions, except CSR which is not significant in the south region, although negative. A greater presence of consanguineous marriages and high-quality maternal and child health care through the public sector in the South makes patrilocality a weaker force in the region to influence excess female child mortality. Moreover, the test of the sensitivity of our findings to the level of urbanization through an interaction of patrilocality and the level of urbanization suggests that the direction of patrilocality and child sex ratios are not affected by the increase in the level of urbanization in the districts.

Table 6: Heterogeneous Effects: The relationship between patrilocality and the regions

\begin{tabular}{|c|c|c|c|c|}
\hline Dependent Variable & $\begin{array}{c}\text { Model } 1 \\
\text { (CSR) }\end{array}$ & $\begin{array}{c}\text { Model } 2 \\
\text { (CSR) }\end{array}$ & $\begin{array}{c}\text { Model } 3 \\
\text { (SRB) }\end{array}$ & $\begin{array}{c}\text { Model } 4 \\
\text { (SRB) }\end{array}$ \\
\hline Patrilocality*North, West, Centre & $-0.0113^{\star \star *}$ & & $-0.0239^{* * *}$ & \\
\hline Region & $(0.00313)$ & & $(0.00373)$ & \\
\hline Patrilocality ${ }^{\star}$ East \& N-E region & $\begin{array}{c}-0.00983^{* * *} \\
(0.00308)\end{array}$ & & $\begin{array}{l}-0.0221^{* * *} \\
(0.00370)\end{array}$ & \\
\hline Patrilocality ${ }^{*}$ South region & $\begin{array}{l}-0.00135 \\
(0.00398)\end{array}$ & & $\begin{array}{l}-0.0124^{* * *} \\
(0.00480)\end{array}$ & \\
\hline Patrilocality*Urbanization & & $\begin{array}{l}-0.00180^{* *} \\
(0.000803)\end{array}$ & & $\begin{array}{c}-0.00599^{* * *} \\
(0.000901)\end{array}$ \\
\hline Control Variables & YES & YES & YES & YES \\
\hline Time Dummy & YES & YES & YES & YES \\
\hline Regional Dummy & & YES & & YES \\
\hline Constant & $\begin{array}{c}6.533^{\star * *} \\
(0.143)\end{array}$ & $\begin{array}{c}6.452^{* * *} \\
(0.136)\end{array}$ & $\begin{array}{c}6.791^{\star * *} \\
(0.167)\end{array}$ & $\begin{array}{c}6.613^{* * *} \\
(0.157)\end{array}$ \\
\hline Observations & 1,238 & 1,238 & 1,238 & 1,238 \\
\hline
\end{tabular}

Note: In Model 2, the interaction term reveals a negative and statistically significant relationship, suggesting that the level of urbanization significantly negatively adjusts the negative impact of patrilocality on CSR and SRB.

\section{Conclusion}

In this study based on a robust econometric assessment, we found a negative relationship between patrilocality and the sex-ratios-CSR, SRB, and SRLB. Additional robustness checks 
corroborate our main results. As we instrument the patrilocality variable with regional dummies we find that the coefficient of the sex ratios is negative and highly significant. Further, the path regression analysis confirms the channels through which patrilocality affects the child sex ratios in India. Based on these findings, we advance the argument that patrilocal culture can be easily converted into economic interpretation on the perceived differentials in the expected returns for parents from boys over girls, thus leading to son preference. In particular, the girl child is considered a liability where she has to move away from the natal kin, lose her identity and devote her life to the husband's family. Hence, to do away with her education, marriage, and especially dowry expenses, parents have been opting for sex-selective abortions and infanticides of a girl child (Kishor, 1993; Jayachandran, 2015; John, 2018). A male child, on the other hand, earns income, stays with the family, carries the lineage, and becomes the old-age support. This entrenched culture engenders the worth of a male child; while undermining a women's autonomy and agency, and rendering her powerless in supporting the birth of a female child (Kishor \& Gupta, 2009; Kaur et al., 2016).

The same arguments are also found in other studies in the global context. For instance, results of this study align with the demonstration by Ebenstein (2014) which also found that the phenomenon of the elderly living with their sons across religions in multiple countries including Hindus in India could majorly explain the skewed sex ratios at birth. The preference for a male child has also been noted through a policy change when China's one-child policy engendered male-based sex ratios. Restricting parents' fertility options has made the parents in China choose a son over a daughter as most of them favor living with sons (Bulte, et al., 2011; Ebenstein, 2014). Findings of this study are further supported using the discussion made by Guilmoto (2012) that patrilocal marriages, where women live with or near husband's kin, deepen the already uneven gender arrangements by not just weakening a mother's economic position, social voice, and other rights but also of her unborn daughter. Looking at the cost-benefit approach in a patrilocal scenario, raising a daughter isn't monetarily feasible for Indian parents while bringing up sons accrue to benefits as they preserve the family's line, are a source of earning and old-age security, and execute funerary rites while daughters are just an added cost (Croll, 2000).

While we empirically verified the existing theory, the most imperative task is to find out the ways that will work on the ground and change this morally and socially unacceptable reality. The abysmal trend of the worsening or stalling progress towards balanced child sex ratios has been observed across a majority of the districts despite incessant work towards female empowerment strategies and laws concerning equal education, employment opportunities, property rights, and access to health care. In particular, menaces such as sex-selective abortions continue to happen, notwithstanding the stricter laws to prevent prenatal sex selection such as the Pre-Natal Diagnostic Techniques (Regulation and Prevention of Misuse) Act, 1994 that amended in 2003 as the Pre-Conception and Pre-Natal Diagnostic Techniques (Prohibition of Sex Selection) Act. Even legislations enacted to empower women such as Dowry Prohibition Act, 1961 (Amended in 1986); Immoral Trafficking Prevention Act, 1986; Equal Remuneration Act, 1976; and Hindu Succession Act, 1956 (Amended in 2020). While these legislations are working at their pace to improve gender equality in multiple dimensions, noteworthy results are not observed in child sex ratios in general and sex ratio at birth in particular. Millions of girls are eliminated even before stepping into the world, tragically snatching away the right to life from the female child.

A more recent government effort of introducing girl child schemes by providing staggered financial incentives to girls and their families has had limited impact in changing the values of girls in the eyes of their parents (Sekher, 2010). Incentives do play an important role in the early years of the girls' life, though it is not sure whether it motivates parents to have daughters (Sekher, 2012). Despite various efforts with multi-pronged strategies, the centuries-old practice of valuing sons 
over daughters continues to persist even in the 21st century 'modern' India, the practical consequences of which would be borne by the future generations in the form of the 'marriage squeeze', leading to mental health issues, more crimes against women, and human trafficking (Tafuro \& Guilmoto, 2020).

In conclusion, we advance that fighting patriarchal attitudes is the key takeaway from this study. The role of safeguarding equal property rights from natal families, ensuring daughters a choice to stay back at the natal family even after marriage, and recognizing the economic and social value of daughters through equal opportunities in education and employment is the most crucial pathway in eliminating gender discrimination. Also, the country needs to inculcate the coming generation with the right perspective on gender norms, equality, individuality, and independence of thought on critical life events such as union formation and fertility preferences.

\section{References}

Agarwal, B. (1986). Women, Poverty and Agricultural Growth in India. Journal of Peasant Studies, 13, 165-220.

Agarwal, B. (2002). Are we not peasants too? Land rights and women's claims in India. New York: SEEDS: Population Council.

Agnihotri, S. B. (2000). Sex Ratio Patterns In The Indian Population. New Delhi: Sage Publications.

Agnihotri, S. B. (2003, October). Survival of the Girl Child: Tunnelling out of the Chakravyuha. Economic and Political Weekly, 38(41), 4351-4360.

Agnihotri, S., Palmer-Jones, R., \& Parikh, A. (2002). Missing women in Indian districts: a quantitative analysis. Structural Change and Economic Dynamics, 13, 285-314.

Allendorf, K. (2013). Going Nuclear? Family Structure and Young Women's Health in India, 1992-2006. Demography, 50, 853-880. Retrieved from www.jstor.org/stable/42919903.

Anderson, S., \& Ray, D. (2010). Missing Women: Age and Disease. The Review of Economic Studies, $77(4), 1262-1300$.

Arnold, F., Kishor, S., \& Roy, T. K. (2002). Sex-Selective Abortions in India. Population and Development Review, 28(4), 759-785.

Arokiasamy, P. (2007). Sex Ratio at Birth and Excess Female. Child Mortality in India: Trends Differentials and Regional Patterns. In I Attané and C Z Guilmoto (Ed.), Watering the. Neighbour's Garden: The Growing Demographic Female Deficit in Asia (pp.49-72). Paris: Committee for International Cooperation in National Research in Demography.

Arokiasamy, P., \& Goli, S. (2012, October 20). Explaining the Skewed Child Sex Ratio in Rural India: Revisiting the Landholding-Patriarchy Hypothesis. Economic and Political Weekly, 47(42), 85-94.

Arokiasamy, P., \& Goli, S. (2012, August). Provisional results of the 2011 Census of India: Slowdown in growth, ascent in literacy, but more missing girls. International Journal of Social Economics, 39(10), 785-801.

Barik, D., Agrawal, T., \& Desai, S. (2015). After the Dividend: Caring for a Greying India. Economic and political weekly, 50(24), 108-112. 
Basu, D., \& Jong, R. D. (2010). Son targeting fertility behavior: Some consequences and determinants. Demography, 47(2), 521-536. doi:https://doi.org/10.1353/dem.0.0110.

Berkman, L. F., Sekher, T. V., Capistrant, B., \& Zheng, Y. (2012). Social networks, family, and caregiving among older adults in India. In Aging in Asia: Findings from new and emerging data initiatives. US: National Academies Press.

Bhat, P. N. (2002). On the Trail of 'Missing' Indian Females: II: Illusion and Reality. Economic and Political Weekly, 37(52), 5244-5263.

Bhat, P. N., \& Zavier, A. J. (2003, November). Fertility decline and gender bias in northern India. Demography, 40(4), 637-57.

Bhat, P. N., \& Zavier, A. J. (2007). Factors Influencing the Use of Prenatal Diagnostic Techniques and the Sex Ratio at Birth in India. Economic and Political Weekly, 42(24), 2292-2303.

Boer, A. d., \& Hudson, V. (2017). Patrilineality, Son Preference, and Sex Selection in South Korea and Vietnam. Population and Development Review, 43(1), 119-147.

Bongaarts, J. (1987). Does family planning reduce infant mortality rates? Population and Development, 13, 323-334.

Bongaarts, J., \& Guilmoto, C. Z. (2015, June). How Many More Missing Women? Excess Female Mortality and Prenatal Sex Selection, 1970-2050. Population and Development Review, 41(2), 241-269.

Bulte, E., Heerink, N., \& Zhang, X. (2011). China's One-Child Policy and 'the Mystery of Missing Women': Ethnic Minorities and Male-Biased Sex Ratios*. Oxford Bulletin of Economics and Statistics, 73(1), 21-39.

Chakravorty, S., Goli, S., \& James, K. S. (2021). Family Demography in India: Emerging Patterns and Its Challenges. Sage Open, 11(2).

Chao, F., Gerland, P., Cook, A. R., \& Alkema, L. (2019, May 7). Systematic assessment of the sex ratio at birth for all countries and estimation of national imbalances and regional reference levels. PNAS, 116(19), 9303-9311.

Chao, F., Guilmoto, C. Z., C., S. K., \& Ombao, H. (2020). Probabilistic projection of the sex ratio at birth and missing female births by State and Union Territory in India. PLOS ONE, 15(8).

Chaudhuri, S. (2012). The Desire for Sons and Excess Fertility: A Household-Level Analysis of Parity Progression in India. International Perspectives on Sexual and Reproductive Health, 38(4), 178186.

Chung, W., \& Gupta, M. D. (2007, February). The Decline of Son Preference in South Korea: The Roles of Development and Public Policy. Population and Development Review, 33(4), 757-783.

Clark, S. (2000). Son Preference and Sex Composition of Children: Evidence from India. Demography, 37(1), 95-108.

Coale, A. J. (1991). Excess Female Mortality and the Balance of Sexes: An Estimate of the Number of 'Missing Females'. Population and Development Review, 17(1), 35-51.

Croll, E. (2000). Endangered Daughters: Discrimination and Development in Asia. London: Routledge.

Das Gupta, M. (1987). Selective discrimination against female children in Punjab, India. Population and Development Review, 13(1), 77-100. 
Das Gupta, M. (2019). Is banning sex-selection the best approach for reducing prenatal discrimination?. Asian population studies, 15(3), 319-336.

Das Gupta, M., \& Bhat, P. N. (1997). Fertility Decline and Increased Manifestation of Sex Bias in India. Population Studies, 51(3), 307-315.

Das Gupta, M., Lee, S., Uberoi, P., Wang, D., Wang, L., \& Zhang, X. (2000). State Policies and Women's Autonomy in China, India, and the Republic of Korea, 1950-2000: Lessons from Contrasting Experiences (Policy Research Working Paper Series 2497). The World Bank.

Das Gupta, M., Zhenghua, J., Bohua, L., Zhenming, X., Chung, W., \& Hwa-Ok, B. (2003). Why is Son Preference so Persistent in East and South Asia? A Cross-Country Study of China, India, and the Republic of Korea. Journal of Development Studies, 40(2), 153-187.

Dube, L. (1988). On the Construction of Gender: Hindu Girls in Patrilineal India. Economic and Political Weekly, 23(18), WS11-WS19.

Duflo, E. (2012). Women Empowerment and Economic Development. Journal of Economic Literature, 50(4), 1051-1079.

Dyson, T. (2012). Causes and consequences of skewed sex ratios. Annual Review of Sociology, 38, 443461.

Dyson, T., \& Moore, M. (1983). On Kinship Structure, Female Autonomy, and Demographic Behavior in India. Population and Development Review, 9(1), 35-60.

Ebenstein, A. (2014). Patrilocality and Missing Women. doi:http://dx.doi.org/10.2139/ssrn.2422090.

Eisenstein, Z. R. (1979). Capitalist patriarchy and the case for socialist feminism. New York: Monthly Review Press.

Facio, A. (2013). What is Patriarchy? Retrieved from http://learnwhr.org/.

Filmer, D., Friedman, J., \& Schady, N. (2009). Development, Modernization, and Childbearing: The Role of Family Sex Composition. The World Bank Economic Review, 23(3), 371-398.

Filser, A., Barclay, K., Beckley, A., Uggla, C., \& Schnettler, S. (2021). Are skewed sex ratios associated with violent crime? A longitudinal analysis using Swedish register data. Evolution and human behavior, 42(3), 212-222.

Guilmoto, C. Z. (2007). Characteristics of Sex-Ratio Imbalance in India, and Future Scenarios. 4th Asia Pacific Conference on Reproductive and Sexual Health and Rights. Hyderabad: UNFPA.

Guilmoto, C. Z. (2009, September). The Sex Ratio Transition in Asia. Population and Development Review, 35(3), $519-549$.

Guilmoto, C. Z. (2012). Sex Imbalances at Birth: Current trends, consequences and policy implications. UNFPA Asia and the Pacific Regional Office.

Guilmoto, C. Z. (2012, March). Son Preference, Sex Selection, and Kinship Selection, and Kinship. Population and Development Review, 38(1), 31-54.

Guilmoto, C. Z. (2015). Mapping the diversity of gender preferences and sex imbalances in Indonesia in 2010. Population Studies, 69(3), 299-315.

Guilmoto, C. Z. (2015). The masculinization of births: Overview and Current Knowledge. Population, 70(2), 201-264. 
Guilmoto, C. Z., \& Depledge, R. (2008, Jan. - Mar.). Economic, Social and Spatial Dimensions of India's Excess Child Masculinity. Institut National d'Etudes Démographiques, 63(1), 91-117.

Guilmoto, C. Z., \& Rajan, S. I. (2002). District Level Estimates of Fertility from India's 2001 Census. Economic and Political Weekly, 37(7), 665-672.

Guilmoto, C. Z., \& Rajan, S. I. (2013, June). Fertility at District Level in India: Lessons from the 2011 Census. Economic and Political Weekly, 48(23), 59-70.

Haddad, L., \& Kanbur, R. (1990). How Serious is the Neglect of Intra-Household Inequality? The Economic Journal, 100, 866-888.

Hudson, V. M., Bowen, D. L., \& Nielsen, P. L. (2011, December). What Is the Relationship between Inequity in Family Law and Violence against Women? Approaching the Issue of Legal Enclaves. Politics and Gender, 7(4), 453 - 492.

Hudson, V. M., Bowen, D. L., \& Nielsen, P. L. (2015, August). Clan Governance and State Stability: The Relationship between Female Subordination and Political Order. American Political Science Review, 109(3), 535 - 555.

James, K. S., Rajan, S. I., \& Goli, S. (2020). Demographic and health diversity in the Era of SDGs. Economic \& Political Weekly, 55(6), 46-52.

Jayachandran, S. (2015). The Roots of Gender Inequality in Developing Countries. Annual Review of Economics, 7, 63-88.

Jayaraj, D., \& Subramanian, S. (2004). Women's wellbeing and the sex ratio at birth: some suggestive evidence from India. Journal of Development Studies, 40(5), 91-119.

Jha, P., Kesler, M. A., Kumar, R., Ram, F., Ram, U., Aleksandrowicz, L., . . Banthia, J. K. (2011). Trends in selective abortions of girls in India: analysis of nationally representative birth histories from 1990 to 2005 and census data from 1991 to 2011. The Lancet, 377(9781), 1921-1928.

Jha, P., Kumar, R., Vasa, P., Dhingra, N., Thiruchelvam, D., \& Moineddin, R. (2006). Low Male-ToFemale Sex Ratio Of Children Born In India: National Survey Of 1.1 Million Households. The Lancet, 367(9506), 211-218.

John, M. E. (2018). The political and social economy of sex selection: exploring family development linkages. New Delhi: UNFPA and UNWomen.

Kaur, R. (2020). Gender and demography in Asia (India and China). Oxford Research Encyclopedia of Asian History. Retrieved from: https://oxfordre.com/asianhistory/view/10.1093/acrefore/9780190277727.001.0001/acrefore9780190277727-e-345.

Kaur, R., \& Vasudev, C. (2019). Son Preference and Daughter Aversion in Two Villages of Jammu. Economic and Political Weekly, 54(13), 13-16.

Kaur, R., Bhalla, S., Agarwal, M. K., \& Ramakrishnan, P. (2016). Sex Ratio at Birth: The Role of Gender, Class, and Education. New Delhi: UNFPA.

Khalil, U., \& Mookerjee, S. (2019). Patrilocal Residence and Women's Social Status: Evidence from South Asia. Economic Development and Cultural Change, 67(2).

Kim, M. (2010). Gender and International Marriage Migration. Sociology Compass, 4(9), 718-31.

Kishor, S. (1993, April). "May God Give Sons to All": Gender and Child Mortality in India. American Sociological Review, 58(2), 247-265. 
Kishor, S., \& Gupta, K. (2009). Gender equality and women's empowerment in India. National Family Health Survey (NFHS-3) India 2005-06. Mumbai: International Institute for Population Sciences.

Kulkarni, P. M. (2007). Estimation of missing girls at birth and juvenile ages in India. Paper commissioned by United Nations Population Fund - UNFPA. Retrieved from: https://www.unfpa.org/sites/default/files/resource-pdf/UNFPA_Publication-39767.pdf

Kulkarni, P. M. (2012). India's Child Sex Ratio: Worsening Imbalance. Indian Journal of Medical Ethics, IX(2), 112-114.

Kulkarni, P. M. (2020). Sex Ratio at Birth in India- Recent Trends and Patterns. New Delhi, India: United Nations Population Fund (UNFPA).

Kumar, S., \& Sathyanarayana, K. M. (2012). District-Level Estimates of Fertility and Implied Sex Ratio at Birth in India. Economic and Political Weekly, 47(33), 66-72.

Kumari, A., \& Goli, S. (2021). Skewed child sex ratios in India: a revisit to geographical patterns and socio-economic correlates. Journal of Population Research, 1-28. https://doi.org/10.1007/s12546021-09277-x

Kuntla, S., Goli, S., \& Jain, K. (2014). Explaining sex differentials in child mortality in India: trends and determinants. International Journal of Population Research, Article ID 649741. https://doi.org/10.1155/2014/649741.sz

Malhotra, A., Vanneman, R., \& Kishor, S. (1995). Fertility, dimensions of patriarchy, and development in India. Population and Development Review, 21(2), 281-305.

Miller, B. D. (1989, June). Changing Patterns of Juvenile Sex Ratios in Rural India, 1961 to 1971. Economic and Political Weekly, 24(22), 1229-1236.

Nandi, A., \& Deolalikar, A. B. (2013). Does a legal ban on sex-selective abortions improve child sex ratios? Evidence from a policy change in India. Journal of Development Economics, 103, 216228.

Palriwala, R., \& Uberoi, P. (2008). Exploring the links: Gender issues in marriage and migration. Marriage, Migration and Gender, 23-60.

Pande, R. P., \& Astone, N. M. (2007). Explaining son preference in rural India: the independent role of structural versus individual factors. Population Research and Policy Review, 26(1), 1-29.

Raju, S. (2011). Gendered geographies: space and place in South Asia. New Delhi: Oxford University Press.

Rammohan, A., \& Vu, P. (2018). Gender Inequality in Education and Kinship Norms in India. Feminist Economics, 24(1), 142-167.

Retherford, R., \& Choe, M. (2011). Statistical models for causal analysis. New York: John Wiley and Sons.

Ritchie, H., \& Roser, M. (2019). Gender Ratio. Our World in Data. Retrieved from https://ourworldindata.org/gender-ratio.

Robitaille, M. C., \& Chatterjee, I. (2018). Sex-selective abortions and infant mortality in India: The role of parents' stated son preference. The Journal of Development Studies, 54(1), 47-56.

Rosenblum, D. (2013). The effect of fertility decisions on excess female mortality in India. Journal of Population Economics, 26(1), 147-180. 
Roy, A., Rai, A., \& Nangia, P. (2018). Skewed sex ratio, male marriage squeeze and cross-cultural marriages: A study of an ecologically vulnerable region in India. Canadian Journal of Tropical Geography, 5(2), 16-24.

Sekher, T. V., \& Hatti, N. (2010). Disappearing daughters and intensification of gender bias: Evidence from two village studies in South India. Sociological Bulletin, 59(1), 111-133.

Sekher, T. V., \& Hatti, N. (2010). Unwanted daughters: Gender discrimination in modern India. Rawat Publications.

Sekher, T.V (2010). Special Financial Incentive Schemes for the Girl Child in India: A Review of Select schemes, United Nations Population Fund, New Delhi. Retrieved from: https://www.unfpa.org/sites/default/files/resource-pdf/UNFPA_Publication-39772.pdf

Sekher, T.V (2012). Ladlis and Lakshmis: Financial Incentive Schemes for the Girl Child in India, Economic and Political Weekly, 57 (17).

Sen, A. (1989). Women's survival as a development problem. Bulletin of the American Academy of Arts and Sciences, 43(2), 14-29.

Sharrow, D., Hug, L., Liu, Y., \& You, D. (2020). Levels \& Trends in Child Mortality. United Nations Interagency Group for Child Mortality Estimation (UN IGME).

South, S. J., Trent, K., \& Bose, S. (2014). Skewed sex ratios and criminal victimization in India. Demography, 51(3), 1019-1040.

Srinivasan, S., \& Bedi, A. S. (2008). Daughter elimination in Tamil Nadu, India: A tale of two ratios. The Journal of Development Studies, 44(7), 961-990.

Sudha, S., \& Irudaya, R. (1999, January). Female demographic disadvantage in India 1981-1991: sexselective abortions and female infanticide. Development and Change, 30(3), 585-618. doi:10.1111/1467-7660.00130.

Sundaram, A., \& Vanneman, R. (2008). Gender Differentials in Literacy in India: The Intriguing Relationship with Women's Labor Force Participation. World Development, 36(1), 128-143.

Tafuro, S., \& Guilmoto, C. Z. (2020, February). Skewed sex ratios at birth: A review of global trends. Early Human Development, 141.

Tandon, S. L., \& Sharma, R. (2006, January). Female Foeticide and Infanticide in India: An Analysis of Crimes against Girl Children. International Journal of Criminal Justice Sciences, 1(1).

UNDP. (2014). Sustaining human progress: Reducing vulnerabilities and building resilience. Human Development Report, UNDP.

Unisa, S., Pujari, S., \& Usha, R. (2007). Sex-Selective Abortion in Haryana: Evidence from Pregnancy History and Antenatal Care. Economic and Political Weekly, 42(1), 60-66. Retrieved from http://www.jstor.org/stable/4419111.

Visaria, P. M. (1967). The sex ratio of the population of India and Pakistan and regional variations during 1901-61. In A. Bose (Ed.), Patterns of Population Change in India, 1951-61 (pp. 334-371).

Bombay: Allied Publishers.

Vishwanath, L. S. (2004). Female Infanticide: The Colonial Experience. Economic and Political Weekly, 39(22), 2313-2318. doi:10.2307/4415098.

Zavier, A. J., \& Bhat, P. N. (2007). Factors Influencing the Use of Prenatal Diagnostic Techniques and the Sex Ratio at Birth in India. Economic \& Political Weekly, 42(24), 2292-2303. 


\section{Appendix}

Figure $1 \mathrm{~A}$. The log linear relationship between patrilocality and childhood sex ratios
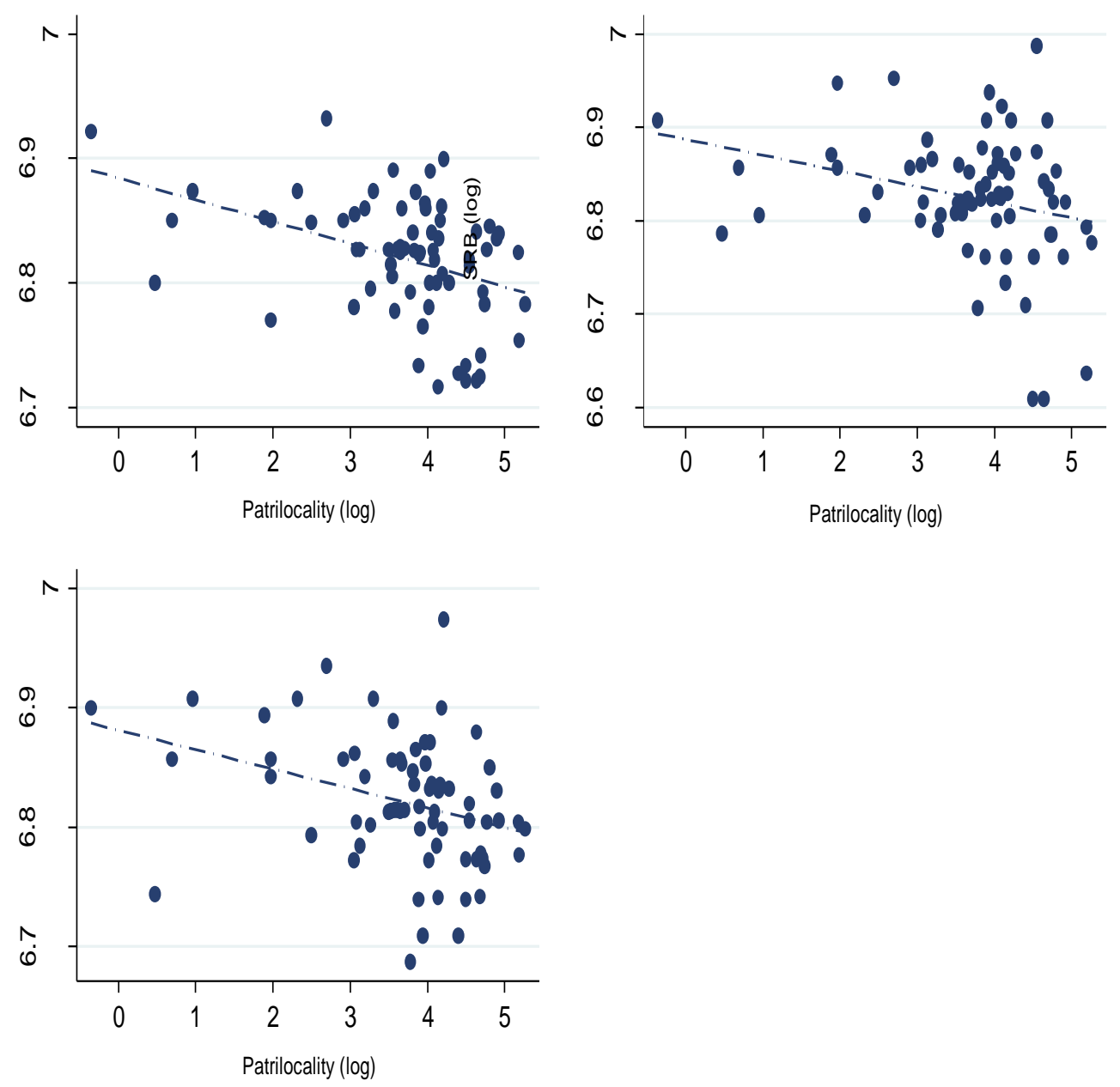